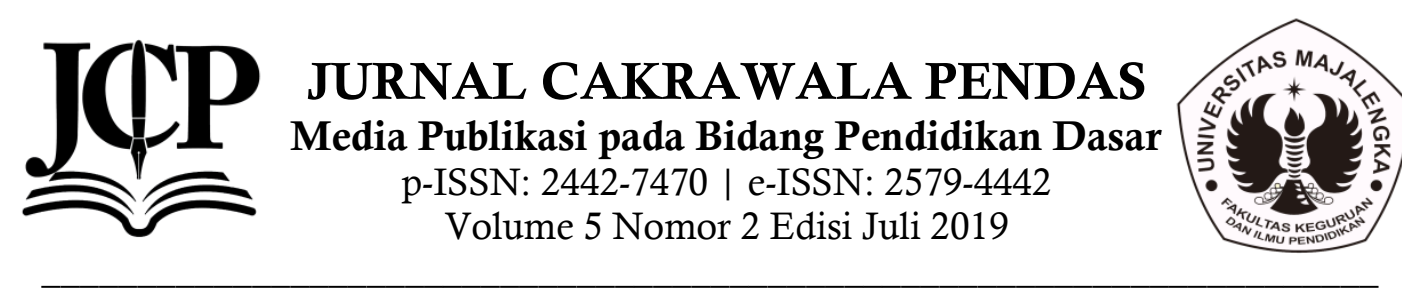

\title{
THE EFFECT OF COLLEGE ACCREDITATION ON STUDENTS' INTEREST OF PUBLIC HIGH SCHOOL NUMBER 1 TANJUNG REDEB TO SELECT THE COLLEGE WITH REVENUE AS MODERATE VARIABLE
}

\author{
Tiarasari Mawi \\ STIE Muhammadiyah Tanjung Redeb \\ tiara.sari@stiemtanjungredeb.ac.id
}

\begin{abstract}
The aims of this study were to find out: (1) the influence of parents' revenue on students' interest in continuing to the college, (2) the effect of accreditation on students' interest in continuing to the college level, (3) the significantly effect of confirmatory variables on the accreditation variables (4) the significantly effect of confirmatory variable towards the variable of interest. This research was conducted at Senior High School N 1 Tanjung Redeb and the instrument of analysis used was Partial Least Square (PLS) with the equation model of Structural Equation Modeling (SEM). The results of this study proved that: (1) Parental revenue did not affect the interest in continuing to the college level, (2) The college accreditation affects the interest of students continuing to the college level, (3) All confirmatory accreditation variables significantly affect the accreditation variable (4) all interest confirmatory variables significantly affect the variable interest. Students misunderstanding in selecting a college for continuing their study. Therefore, this is a consideration in conducting this research. Meanwhile, the geographical conditions and the limitations of the existing the Colleges at Tanjung Redeb Regency make students have limitation in developing their talents.
\end{abstract}

Keywords: one or more word(s) or phrase(s), that it's important, spesific, or representative for the article 


\section{INTRODUCTION}

In order to achieve excellent and qualified education, the government has compiled regulations on education standards set out in detail in the 2005 under Government Regulation on National Education Standards. This National Education Standard was a minimum criterion of the education system in all authority of the Unity of the Republic of Indonesia. The standardization program was integrated into three programs, namely are standardization, accreditation and certification.

In related to this standardization, accreditation was one of the important core in an effort to obtain information about the real conditions of an educational institution based on the minimum standards set towards targeted education planning in order to realize quality national education goals. In PP No. 19 of 2005, the government mandates an accreditation program for educational institutions, mentioned in Chapter XIII subsection 86 (1) the government carries out accreditation at every level and education unit to determine the feasibility of programs and educational units.

Accreditation was important for private universities because the existence of accreditation status will affect the acquisition of the number of students and the composition of lecturers at private universities. Accreditation was a matter of consideration where students can determine their selection in selecting college according to National Regulation 2009, the data showed that students are input the amount $20 \%$ where students, environment and instrumental are part of it, then amount $50 \%$ process with details of governance, program management, learning process, academic atmosphere, information system, quality assurance system while output or outcome was $30 \%$, consisting of graduates, research, publications and final assignments.

Based on the explanation of the importance of accreditation and the impact caused by the quality of a university, researchers endeavor that students who will study at the University have sufficient information in advance about considerations in selecting students' future goals, but based on the observations of this researcher at schools in Tanjung Redeb, the data showed that there were still many students who did not understand the meaning of accreditation of the college while the effect of excellent accreditation of the college has an important role in improving the character (effective) of the students, improve their cognitive intelligence by selecting the best college, therefore their competence has an impact on students' maturity to solve a problem in the future in the working area.

The economic status of parents was important part in a society in order to fulfil their needs and achieve prosperity. Nowadays in an increasingly modern era, there are many facilities or places to continue their studies in college. Many options of education are conditioned with best facilities, luxuries class and good management, and high -priced causing students to be more selective in selecting which education was suitable for their abilities and in accordance with the economic conditions of their parents.

However, to obtain such education, a number of costs are needed. The high cost of education sometimes becomes an obstacle for those poor families. Many of them were forced to drop out of school or were unable to continue their college studies, due to limited costs and poor of economic status.

Meanwhile, the condition after the student graduated from high school they would be faced with two option namely were continuing their studies or working. If the students decided to continue their study whether was the biggest factor in fulfilling their decision.

\section{Theoritical Review}

Interest in presenting actions (represent motives) interest cannot be classified as disposition but its nature can be cultivated, studied, and developed. Markseffel in Bafadal (2001: 191) explains interest that "Summarizing our discussion of interest thus far indicates that (1) interest are not in born but are learned, acquired, and developed; (2) interest are related to meaning; (3) interests are closely associated with a person's social and 
emotional health and; (4) interest are in some manner capable of initiating and directing human behaviour.

According to Curran and Rosen (2016:135) "An attitude was defined as "a psychological tendency that was expressed by evaluating a particular entity with some degree of favour or disfavour". And this limitation can be stated that if an individual has an interest in an object then this attention will automatically be attracted to the object and tends to give greater attention to the object.

According to Hamalik (1990: 97) the emergence of one's interests can also be caused by the environment or social institutions such as family, play groups, schools and so on. Elizabeth B Hurlock (1994: 2016) states that interest depends on intelligence, environment, opportunities to develop interests peer interest, status in social groups, innate abilities, family interests and many other factors. A person's interest does not arise suddenly. This interest was due to the influence of two factors, namely internal and external factors.

Slameto (2010: 63) argues that the economic situation of the family was closely related to children's learning. Children who are learning besides their basic needs must be fulfilled, such as eating, drinking, clothing, health protection, also need learning facilities such as study rooms, tables, chairs, lighting, stationery, books and others. Learning facilities can only be fulfilled if parents have enough money. If the child lives in a poor family, the basic needs of the child are not fulfilled so that the child's learning was disrupted. As a result of the other children are always afflicted with sadness so that children feel inferior to their friends, this will also interfere with children's learning.

Accreditation from Spanish, Agency Nacional de Evaluacion de la Calidad Y Accreditation (ANECA, 2012) provides an explanation of accreditation as follows:

Accreditation refers to the process of evaluation of studies leading to official degrees (bachelor, master's and doctoral degrees), "in order to fulfil the criteria and standards previously established for each type of degree". The methodology of the evaluation for accreditation includes the following: self-assessment, external assessment, draft report on accreditation, and a final report by the Ministry leading to acceptance or cancellation of the programme. Accreditation ex-post of programmes: ex-post assessment process leading to a public, formal and independent decision on the adaptation of a programme to certain preestablished quality standards; the process can lead to the loss of the right to impart a given degree.

\section{Framework Of The Research}

The following was the framework of the research:

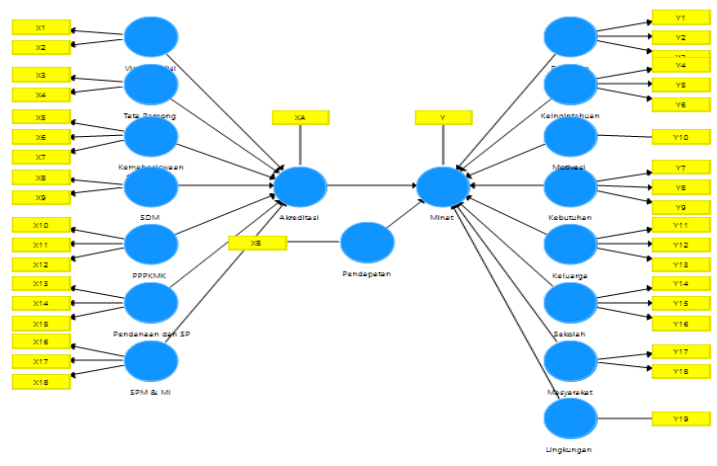

Information:

- Xa: independent variable

- Xb: moderate variable

- Y: dependent variable

Based on the problems, literature and conceptual framework, the hypothesis of this study were:

$\mathrm{H1}=$ There was an effect of parents' revenue on the students interest of Public High School N 1 Tanjung Redeb in selecting College.

$\mathrm{H} 2$ = There was the effect of university accreditation on the interest of Public High School N 1 Tanjung Redeb in selecting College.

H3 = There was a significant effect of the confirmation variable to the accreditation variable.

$\mathrm{H} 4=$ There was significant effect of the confirmation variable to the interest variables.

\section{Research Methods}

In this study the data analysis was used the Partial Least Square (PLS) 
approach. PLS was a model based on Structural Equation Modeling (SEM) based on component based or component based with a sample of 100 people.

\begin{tabular}{cccc}
\hline$\alpha$ & $1-\alpha$ & $\mathrm{Z} 1-\alpha / 2$ & $\mathrm{Z} 1-\alpha$ \\
\hline $1 \%$ & $99 \%$ & 2,58 & 2,33 \\
\hline $5 \%$ & $95 \%$ & 1,96 & 1,64 \\
\hline $10 \%$ & $90 \%$ & 1,64 & 1,28 \\
\hline
\end{tabular}

$$
\begin{aligned}
n & =\frac{Z^{2} 1-\alpha / 2 P(1-P)}{d^{2}} \\
n & =\frac{1.96^{2} \times 0.50 x(1-50)}{0.1^{2}} \\
n & =\frac{1.96^{2} \times 0.50 \times 0.50}{0.01} \\
n & =96.04 \\
n & =100(\text { dibulatkan })
\end{aligned}
$$

Information :

$\mathrm{n}=$ Number of samples

$Z=z$ score based on the desired $\alpha$ value

$\mathrm{P}=$ The proportion of students continuing

college

$\mathrm{q}=1-\mathrm{P}$ (Proportion of students who do not continue their studies)

$d=$ the level of trust / error that can be tolerated

The parameter estimates obtained with PLS can be categorized into three parameters. First was the weight estimate, the second was path estimate. Then Third, related to means of data, Meanwhile, to obtain these three estimates, PLS uses a 3stage iteration process and each iteration stage produces estimates. The first stage, produces weight estimate, the second stage produces estimates for the inner model and outer model, and the third stage produces estimates of means and location (Ghozali, 2014).

\section{Discussion}

Assessing the Outer model

There are three criteria to assess the Outer model, namely were Convergent Validity, Dwascriminant Validity and Composite Reliability.

Table 1, Outer Loading Eksogen (Measurement Model

\begin{tabular}{cc}
\hline Indicator & Accreditation Variable \\
\hline $\mathrm{XA}$ & 1,000
\end{tabular}

Based on the iteration results using SmartPLS 3.0 it was known that the Outer Loading value of the Accreditation variable was 1.0 , it indicates that the accreditation variable can be used in research.

Table 1, Outer Loading Revenue variables Indicator Revenue Variables

\begin{tabular}{cc}
\hline $\mathrm{XB}$ & 1,000 \\
\hline
\end{tabular}

Based on the iteration results using SmartPLS 3.0, it was known that the Outer Loading value of the revenue variable was 1.0 , it indicates that the revenue variable can be used in the study.

Table 3, Outer Loading variables Confirm Vision \& Mission

\begin{tabular}{cc}
\hline Indicator & VK Vision \& Mission \\
\hline $\mathrm{X} 1$ & 0.897 \\
\hline $\mathrm{X} 2$ & 0.782 \\
\hline
\end{tabular}

Table 4, Outer Loading variable Confirmation of Civil Service

\begin{tabular}{cc}
\hline Indicator & VK Governance \\
\hline $\mathrm{X} 3$ & 0.892 \\
\hline $\mathrm{X} 4$ & 0.831 \\
\hline
\end{tabular}

Table 5, Outer Loading Confirmatory Student and Graduate variables

\begin{tabular}{cc}
\hline Indicator & VK Student \& Graduates \\
\hline $\mathrm{X} 5$ & 0.772 \\
\hline $\mathrm{X} 6$ & 0.864 \\
\hline $\mathrm{X} 7$ & 0.767 \\
\hline
\end{tabular}

Table 6, Outer Loading Confirmatory HR variable

\begin{tabular}{cc}
\hline Indicator & VK Human Resources \\
\hline $\mathrm{X} 8$ & 0.927 \\
\hline $\mathrm{X} 9$ & 0.671 \\
\hline
\end{tabular}

Table 7, Outer Loading Confirmatory variable PPPKMK

\begin{tabular}{cc}
\hline Indicator & VK PPPKMK \\
\hline $\mathrm{X} 10$ & 0,659 \\
\hline $\mathrm{X} 11$ & 0,574 \\
\hline $\mathrm{X} 12$ & 0,741 \\
\hline
\end{tabular}


Table 8, Outer Loading Confirmatory Financing variables

\begin{tabular}{cc}
\hline Indicator & VK Finance \& SP \\
\hline $\mathrm{X} 13$ & 0,877 \\
\hline $\mathrm{X} 14$ & 0,793 \\
\hline $\mathrm{X} 15$ & 0,848 \\
\hline
\end{tabular}

Table 9, Confirmator SPM Outer Loading variable

\begin{tabular}{ll}
\hline Indicator & $\begin{array}{l}\text { SPM Information } \\
\text { Management }\end{array}$ \\
\hline $\mathrm{X} 16$ & 0,827 \\
\hline $\mathrm{X} 17$ & 0,820 \\
\hline $\mathrm{X} 18$ & 0,784 \\
\hline
\end{tabular}

Based on the iteration results using SmartPLS 3.0, it was known that the Outer Loading value of the Confirmatory SPM \& Information Management variable was $0.827,0.820$ and 0.784 , where the standard outer loading value used was $>0.5$, it indicates that the Confirmatory SPM \& Information Management variables can be used in research.

Based on the results of the above iterations it was known that all confirmatory variables accreditation variables have very good loading values and can be used in research

Tabel 10 , Outer Loading Endogen (Measurement Model)

\begin{tabular}{cc}
\hline Indicator & Variable Interest \\
\hline $\mathrm{Y}$ & 1,000 \\
\hline
\end{tabular}

Table 11, Outer Loading variable Confirmation Attention

\begin{tabular}{cc}
\hline Indicator & VK Attention (Internal) \\
\hline Y1 & 0.778 \\
\hline Y2 & 0.818 \\
\hline Y3 & 0.838 \\
\hline
\end{tabular}

Table 12, Outer Loading variable Confirmation Curiosity

\begin{tabular}{cc}
\hline Indicator & VK Curiosity \\
\hline Y5 & 0.711 \\
\hline Y6 & 0.846 \\
\hline
\end{tabular}

Table 13, Outer Loading Confirmatory

Motivation variable

\begin{tabular}{cc}
\hline Indicator & VK Motivation \\
\hline Y7 & 0.772 \\
\hline
\end{tabular}

\begin{tabular}{ll}
\hline $\mathrm{Y} 8$ & 0.864 \\
\hline $\mathrm{Y} 9$ & 0.767 \\
\hline
\end{tabular}

Table 14, Outer Loading Confirmatory variable needs

\begin{tabular}{cc}
\hline Indicator & VK Requirement \\
\hline Y10 & 0.772 \\
\hline
\end{tabular}

Table 15, Outer Loading Variable

Confirmation of the family

\begin{tabular}{cc}
\hline Indicator & Family VK (External) \\
\hline Y11 & 0,718 \\
\hline Y12 & 0,785 \\
\hline Y13 & 0,601 \\
\hline
\end{tabular}

Table 16, Outer Loading Variable Confirmation school

\begin{tabular}{cc}
\hline Indicator & VK School \\
\hline Y14 & 0,774 \\
\hline Y15 & 0,816 \\
\hline Y16 & 0,800 \\
\hline
\end{tabular}

Table 17, Outer Loading Confirmatory variable society

\begin{tabular}{cc}
\hline Indicator & VK Society \\
\hline Y17 & 0,733 \\
\hline Y18 & 0,897 \\
\hline Y19 & 0,826 \\
\hline
\end{tabular}

Table 18

\begin{tabular}{lcc}
\hline \multicolumn{1}{c}{ Variable } & $\begin{array}{c}\text { Composite } \\
\text { Reliability }\end{array}$ & $\begin{array}{c}\text { Average } \\
\text { Variance } \\
\text { Extracted } \\
\text { (AVE) }\end{array}$ \\
\hline accreditation & 1,000 & 1,000 \\
\hline K\&L & 0,844 & 0,644 \\
\hline Needs & 1,000 & 1,000 \\
\hline Curiosity & 0,757 & 0,611 \\
\hline Family (external) & 0,746 & 0,498 \\
\hline Society & 0,861 & 0,675 \\
\hline Interest & 1,000 & 1,000 \\
\hline Moderating Effect 1 & 1,000 & 1,000 \\
\hline Motivation & 0,779 & 0,540 \\
\hline PPPKMK & 0,698 & 0,438 \\
\hline Funding \& Sapras & 0,878 & 0,706 \\
\hline Revenue & 1,000 & 1,000 \\
\hline attention (internal) & 0,853 & 0,659 \\
\hline SDM & 0,787 & 0,655 \\
\hline SPM \& Manajemen & 0,852 & 0,657 \\
Infor & 0,839 & 0,635 \\
\hline School & 0,853 & 0,744 \\
\hline Governance & 0,828 & 0,708 \\
\hline Vision and Mission & &
\end{tabular}


Based on the iteration results using SmartPLS 3.0, it was known that the Outer Loading value of the Confirmatory variable was $0.733,0.897$ and 0.826 , where the standard outer loading value used was $>0.5$, it indicates that the Confirmatory variable of society can be used in research

The results of processing using smartPLS 3.0 can be seen in table 17. Outer model value of correlation between construct and variable was very good and meets the qualifications of Convergent Validity assessment where many indicators have Loading factor values above 0.5 except confirmatory variable curiosity $\mathrm{X} 4$ which has a value of $<0.5$, so it must be discriminant.

\section{Discriminant Validity}

Discriminant Validity was done to see that each construct of each latent variable was different from the other variables. A structural model has good discriminant validity if the loading value of each indicator of the latent variable has the highest loading value with other loading values towards the other latent.

Reliability and Average Variance Extracted (AVE)

In this study also uses the reliability assessment of a contract and Average Variance Extracted (AVE) of each construct. The research construct has high reliability if it has a value of $>0.7$ and AVE $>0.5$. The reliability and AVE values after iterations are as follows:

Based on the table, it can be concluded that all constructs meet reliable criteria except the PPPKMK construct which has a value of 0.698 and AVE value of 0.438 . It showed that the PPPKMK construct was not too affect and was considered insignificant towards students' interest in continuing their studies.

In addition, there was also a family confirmation variable (External) which has an AVE value of 0.498 , where the value was lower than the specified standard which was $>0.5$.

Calibration model of structural (Inner Model)

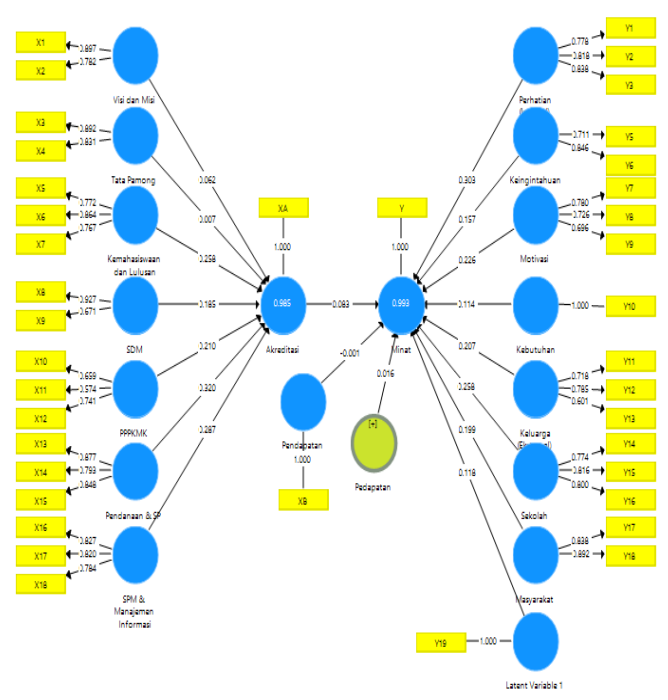

Structural model testing was carried out to see the relationship between constructs of the research variables using the significance and R-square values of the research model. Structural models were assessed using R-square for exogenous constructs $t$ test and significance of path parameter coefficients. In assessing the structural model with PLS seen from the values indicated by $\mathrm{R}$-square for each dependent latent variable.

Tabel 19, Nilai $R$-square

\begin{tabular}{ll}
\hline Var & R-Square \\
\hline Akreditasi & 0,985 \\
\hline Minat & 0,993 \\
\hline
\end{tabular}

The table above showed that the $\mathrm{R}$ square value for the Accreditation variable of 0.985 or $98.5 \%$ and for the Interest variable obtained at 0.993 or $99.3 \%$. It indicates that 0.985 accreditation variables can be affected by other confirmatory variables, 0.993 variables of interest are influenced by revenue variables and other confirmation variables.

\section{Conclusion}

Based on the results of research and discussion about the effect of college accreditation and parents 'revenue on the students' interest at Public High School N 1 Tanjung Redeb, some conclusions can be obtained that do not affect students' interest in continuing, but the accreditation of a 
college has an influence on student interest, and confirms significantly affect the accreditation towards the accreditation variable, the confirmatory interest variables significantly influence the variable interest.

\section{References}

Bafadal,Ibrahim. 2001. Pengelolaan Perpustakaan Sekolah. Malang: Bumi Aksara.

Curran, James and Rosen. 2016. Media and Demokrasi. Routledge Taylor and Francwas Group.

Crow. 1984. Psikologi Pendidikan. Terjemahan Rochman Abror. Yogyakarta: Nur Cahaya.

Djaali. 2008. Psikologi Pendidikan. Jakarta: Bumi Aksara

Djalil. 2012. Analwaswas Pengaruh Motivasi Terhadap Prestasi Kerja Melalui Kepuasan dan Dwasiplin Kerja Pegawai. Jurnal Sains Manajemen 1(1) Halaman : 98-111.

Gunawan. 2008. "Analwaswas Pengaruh Status Akreditasi dan Perubahan Kurikulum terhadap Minat Belajar Mahaswaswa Prodi Ekonomi Waslam Jurusan Syariah STAIN Kudus". Skripsi. Kudus: STAIN Kudus.

Hamalik, Oemar. 2004. Proses Belajar Mengajar. Bumi Aksara. Jakarta.

Hmadi, Abu dan Nur Uhbiyanti. 1991. Ilmu Pendidikan. Jakarta: Rineka Cipta.

Hurlock, Elizabeth B. 1997. Psikologi Perkembangan Suatu pendekatan rentang kehidupan. Edwasi kelima: Erlangga

James, M Curran, J.M \& Deborah,E.R. 2006. Student Attitudes Toward College Courses: An Examination of Influences and Intention. Journal of Marketing Education, 28(2),135-148

Meilina. 2016. "Pengaruh Tingkat Pendapatan Orang Tua, Manajemen Waktu Dan Self-Efficacy Terhadap Prestasi Belajar Ekonomi Swaswa Kelas XI IWAS Negeri 1
Karanganom Klaten". Skripsi. Yogyakarta : Universitas Negeri Yogyakarta.

Mulyasa. 2003. Kurikulum Berbaswas Kompetensi. Bandung: Remaja Rosdakarya.

Nasution. 2003. Berbagai Pendekatan dalam Proses Belajar \& Mengajar. Jakarta : Bumi Aksara

Undang-Undang Republik Indonesia Nomor 20 Tahun 2003 tentang Swastem Pendidikan Nasional.

Prasetyo. (2014). "Dampak Kebijakan Akreditasi Perguruan Tinggi Terhadap Daya Saing (Competitiveness) Perguruan Tinggi Swasta di Kabupaten Kebumen" (Vol. 13). Jurnal Fokus Bwasnwas.

Pujiati. 2009. "Pegaruh Kondwasi Sosial dan Ekonomi Orang Tua terhadap motivasi melanjutkan ke Perguruan Tinggi pada swaswa Kelas XI SMA Negeri dan Swasta di Kabupaten Pati". Skripsi. Semarang: Universitas Negeri Semarang.

Rahayu. 2013. "Minat Swaswa Melanjutkan Studi ke Perguruan Tinggi Ditinjau dari Prestasi Belajar, Motivasi Belajar, dan Status Soswasal Ekonomi Orang Tua pada Swaswa Kelas XI IIPS SMA Negeri Jumapolo Tahun Ajaran 2012/2013". Skripsi. Purworejo: Universitas Muhammadiyah Purworejo

Slameto. 2010. Belajar dan Faktor-faktor yang Mempengaruhinya. Jakarta: Rineka Cipta

Suryabrata, S. 2007. Psikologi Pendidikan. Jakarta: PT Raja Grafindo Persada 